Article

\title{
Copy Number Variations and Expression Levels of Guanylate-Binding Protein 6 Gene Associated with Growth Traits of Chinese Cattle
}

\author{
Dan Hao ${ }^{1,2,+} \mathbb{C}$, Xiao Wang ${ }^{3,+}{ }^{,}$Bo Thomsen ${ }^{2}$, Haja N. Kadarmideen ${ }^{3} \mathbb{C}$, Xiaogang Wang ${ }^{1}$, \\ Xianyong Lan ${ }^{1}$, Yongzhen Huang ${ }^{1}\left(\mathbb{D}\right.$, Xinglei $\mathrm{Qi}^{4}$ and Hong Chen ${ }^{1, *}$ \\ 1 College of Animal Science and Technology, Northwest A\&F University, Shaanxi Key Laboratory of Animal \\ Genetics, Breeding and Reproduction, Yangling 712100, Shaanxi, China; haodan111121@163.com (D.H.); \\ wangxiaogang0401@163.com (X.W.); lan342@126.com (X.L.); hyzsci@126.com (Y.H.) \\ 2 Department of Molecular Biology and Genetics, Aarhus University, 8000 Aarhus C, Denmark; \\ bo.thomsen@mbg.au.dk \\ 3 Department of Applied Mathematics and Computer Science, Technical University of Denmark, \\ 2800 Kongens Lyngby, Denmark; xiwa@dtu.dk (X.W.); hajak@dtu.dk (H.N.K.) \\ 4 Bureau of Animal Husbandry of Biyang County, Biyang 463700, Henan, China; byq273@126.com \\ * Correspondence: chenhong1212@263.net; Tel.: +86-029-8709-2102 \\ + These authors contributed equally to this work.
}

Received: 26 February 2020; Accepted: 22 March 2020; Published: 27 March 2020

check for updates

Simple Summary: Our study identified the copy number variations (CNVs) and transcriptional expressions of guanylate-binding protein 6 (GBP6) in Chinese cattle, as well as analyzed the association of CNVs and expressions with the growth traits of Chinese cattle. The results showed Xianan cattle with gain types ( $\left.\log _{2} 2^{-\Delta \Delta C t}>0.5\right)$ of CNVs of GBP6 had highest relative gene expression levels in the muscle tissues and displayed superior phenotypic values of body weight, cannon circumference and chest circumference. Our study suggested that CNV gain types of GBP6 could be used as the candidate markers in the cattle-breeding program for growth traits.

\begin{abstract}
Association studies have indicated profound effects of copy number variations (CNVs) on various phenotypes in different species. In this study, we identified the CNV distributions and expression levels of guanylate-binding protein 6 (GBP6) associated with the growth traits of Chinese cattle. The results showed that the phenotypic values of body size and weight of Xianan (XN) cattle were higher than those of Nanyang (NY) cattle. The medium CNV types were mostly identified in the XN and NY breeds, but their CNV distributions were significantly different (adjusted $p<0.05$ ). The association analysis revealed that the body weight, cannon circumference and chest circumference of XN cattle had significantly different values in different $\mathrm{CNV}$ types $(p<0.05)$, with $\mathrm{CNV}$ gain types $\left(\log _{2} 2^{-\Delta \Delta C t}>0.5\right)$ displaying superior phenotypic values. We also found that transcription levels varied in different tissues $(p<0.001)$ and the CNV gain types showed the highest relative gene expression levels in the muscle tissue, consistent with the highest phenotypic values of body weight and cannon circumference among the three CNV types. Consequently, our results suggested that CNV gain types of GBP6 could be used as the candidate markers in the cattle-breeding program for growth traits.
\end{abstract}

Keywords: cattle; GBP6; CNVs; growth traits 


\section{Introduction}

Structural variations (SVs) in the genome refer to DNA sequence polymorphisms in the fragment lengths with a dozen or hundreds of bases, which have larger effects on phenotypic variations than SNPs [1]. As one category of SVs, copy number variations (CNVs) are defined as the type of large segments of DNA that are repeated and they vary in copy-number [2]. Generally, CNVs include insertions, deletions and duplications in a simple or complex structure, such as gains or losses of heterozygous or homologous sequences at multiple sites [3]. Single nucleotide polymorphisms (SNPs), the single nucleotide genetic variation in the genome, enable most of the common variations to be captured and genetic changes related to complex traits to be detected by many association studies [4]. However, a great difference between different individual genomes was caused by CNVs, which cover more base pairs than the per-locus mutations of SNPs and result in dramatic phenotypic consequence $[5,6]$.

Recently, association studies indicate that CNVs have profound effects on various phenotypes including diseases (e.g., neurological and developmental diseases) $[7,8]$ and non-pathogenic traits (e.g., height) [9] in humans. In domestic animal species, researchers have summarized the associations of CNV with pea-comb phenotype, late feathering, dark brown plumage and dermal hyperpigmentation in chickens [10]. Yang et al. [11] also found that several copy number variation regions (CNVRs) were involved in fetal muscle development, prostaglandin synthesis and bone color traits of sheep. Since the first CNV snapshot analysis identified 37 CNVRs in the pig genome across chromosomes 4, 7, 14, and 17 [12], a number of reports have identified CNVs related to carcass [13], disease [14], meat quality [15] and fatty acid composition [16] traits in pigs. Similarly, a series of CNV studies in cattle suggested a relationship with milk production [17], meat tenderness [18], immune system [19], feed efficiency [20] and fertility [21] traits. In beef cattle, $17 \mathrm{CNVs}$ were identified to associate with seven different body traits [22]. Moreover, CNVs of ten genes (CYP4A11, GBP2, GPC1, KCNJ12, KLF3, KLF6, LEPR, MAPK10, $M I C A L L 2$ and $M Y H 3)$ were identified in correlation with transcript expression levels and growth traits (e.g., body length and body weight) of Chinese domestic cattle in the previous CNV studies [23-32].

Guanylate-binding protein (GBP) with a molecular weight of $67-73$ kilodalton $(\mathrm{kDa})$ belongs to the superfamily of guanosine triphosphatases (GTPases) that could hydrolyze guanosine-5' -triphosphate (GTP) to guanosine-5'-diphosphate (GDP) and guanosine-5'-monophosphate (GMP) [33]. GBPs play the important roles in multitude of cellular processes (e.g., signal transduction, translation, vesicle trafficking, and exocytosis) [34] and have functions on the membrane of host and pathogen to mediate cell-autonomous host resistance in some infections [35]. Previous studies have revealed that the CNVs of the GBPs (e.g., GBP2 and GBP4) were associated with growth traits in Chinese domestic cattle [24,36]. In addition, GBP6 was found in an overlap with CNV204 which was significantly associated with growth trait of Nellore cattle at the weaning stage [22]. Furthermore, GBP6 is located in CNVR37 that were overlapped with the quantitative trait loci (QTLs) of meat and carcass traits in Chinese bulls [37]. Transcriptome analysis also revealed that GBP6 was differently expressed in two kinds (i.e., tough and tender) of longissimus dorsi in Angus cattle. The expression level of GBP6 was up-regulated in the tough beef tenderness [38].

Nevertheless, few studies are conducted to interpret the relationships between CNVs and expression levels of GBP6 associated with growth traits in Chinese domestic cattle. Therefore, the aim of this study was to identify the GBP6 CNVs and expressions in six different Chinese beef cattle breeds, and to reveal their possible associations with growth traits, which could provide valuable molecular information regarding the usage of GBP6 in the breeding programs of beef cattle.

\section{Materials and Methods}

\subsection{Animals and Phenotypes}

A total of 524 Chinese female beef cattle in six breeds were involved in this study, including 112 Nanyang (NY) cattle, 105 Qinchuan (QC) cattle, 213 Xianan (XN) cattle, 32 Denan (DN) cattle, 
32 Xiajia (XJ) cattle and 30 Zaosheng (ZS) cattle. They were collected from six farms of six regions, respectively (Figure 1). The six farms were mainly situated in the central and northwest regions of China (Figure 1). The map of three provinces (i.e., Gansu, Henan and Shaanxi) was realized by $\mathrm{R}$ package maptools (version 0.9-5) using geographic information system (GIS) basic data of China. The average temperatures $\left({ }^{\circ} \mathrm{C}\right)$ and precipitations $(\mathrm{mm})$ were calculated using the data over past thirty years from the national meteorological information center of China (http://data.cma.cn).

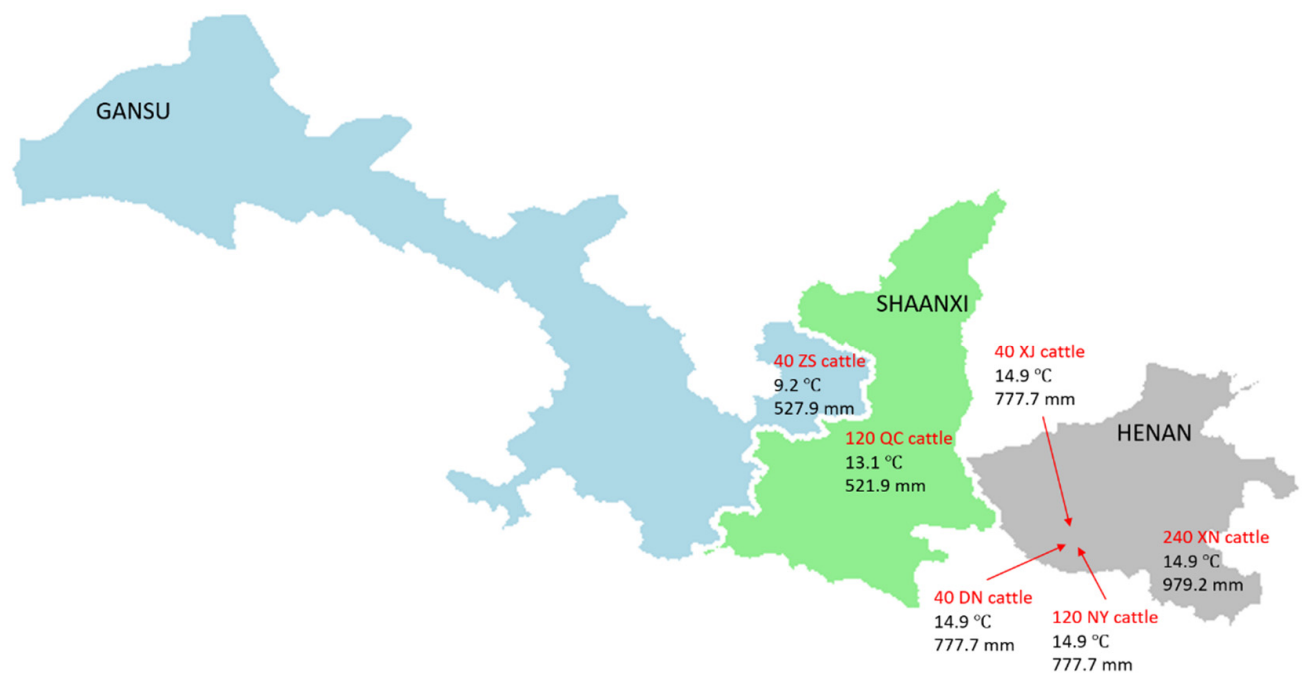

Figure 1. Map of regions for sample collections and their average temperatures $\left({ }^{\circ} \mathrm{C}\right)$ and precipitations $(\mathrm{mm})$ over past thirty years.

Using the measurement methods of Gilbert et al. [39], we recorded twelve phenotypes for NY, QC and $\mathrm{XN}$ cattle that included body height $(\mathrm{BoH}, \mathrm{cm})$, body length $(\mathrm{BoL}, \mathrm{cm})$, body weight $(\mathrm{BoW}, \mathrm{kg})$, cannon circumference $(\mathrm{CaC}, \mathrm{cm})$, chest circumference $(\mathrm{ChC}, \mathrm{cm})$, chest depth $(\mathrm{ChD}, \mathrm{cm})$, chest width $(\mathrm{ChW}, \mathrm{cm})$, cross height $(\mathrm{CrH}, \mathrm{cm})$, hucklebone width $(\mathrm{HuW}, \mathrm{cm})$, rump length $(\mathrm{RuL}, \mathrm{cm})$ and waist circumference $(\mathrm{WaC}, \mathrm{cm})$. Only four phenotypes (i.e., $\mathrm{BoH}, \mathrm{BoL}, \mathrm{BoW}$ and $\mathrm{ChC}$ ) were measured in the animals of NY, QC and XN breeds. However, no phenotypic measurement was performed for the other breeds (i.e., $\mathrm{DN}, \mathrm{XJ}$ and $\mathrm{ZS}$ ) due to the commercial limitations on these farms. All cattle were measured at 2 years of age, when they were ready for harvest in a commercial slaughterhouse.

\subsection{DNA and RNA Extractions}

All animal experiments were approved by the Animal Care Commission of the College of Veterinary Medicine, Northwest A\&F University (Permit Number: NWAFAC1019). Blood samples were collected from each animal through the jugular vein into a vacuum tube. Additionally, we selected 12 cattle including 9 QC cattle in three age stages (i.e., fetal at 90 days of gestation, newborn calves and adult cattle; each stage included 3 cattle) with three replicates at each age stage and $3 \mathrm{XN}$ cattle only in the adult age stage due to commercial limitations. Then, seven tissue samples (i.e., heart, kidney, liver, longissimus dorsi muscle, lung, spleen and subcutaneous fat) with three replicates were collected from each age stage of each selected animal from the QC and XN breeds. After the identification of CNV type, another 9 tissue samples of longissimus dorsi muscle were collected from $\mathrm{XN}$ adult cattle for the further gene expression validation of growth traits. Blood and tissue samples were immediately stored in the liquid nitrogen for genomic DNA and RNA extractions, respectively.

As TRIzol or TRI reagent is advantageous to RNA purification [40], this study used TRIzol (Takara, Dalian, China) to treat RNA as RNase-free DNase for RNA extraction from tissue samples. Then, $1 \%$ agarose gel electrophoresis and spectrophotometry measurement were conducted to estimate the density and the purity of RNA. With $1 \mu \mathrm{g}$ RNA as the template, StarScript II One-step RT-PCR Kit with 
genomic DNA Eraser (GenStar, Beijing, China) resulted in reverse transcription in complementary DNA (cDNA).

\subsection{Primers Design for Quantitative Polymerase Chain Reaction Amplification}

Two pairs of primers on GBP6 for quantitative polymerase chain reaction (qPCR) amplification were designed by Primer Premier software (version 6.2.4) (http://www.premierbiosoft.com). The first and second primer pairs were located in the first intron and third exon regions of $G B P 6$, respectively (Figure 2). The genomic location of GBP6 (AC_000160.1) was identified based on Bos taurus genome of Bos_taurus_UMD_3.1 version. The genomic primer positions on the gene structure of GBP6 were visualized by Illustrator for Biological Sequences (IBS) software (version 1.0). The correlation coefficient of the two primers of GBP6 in the PCR efficiency was nearly $100 \%$. In addition, the results of CNV identification using two primers were the same, thus, we chose the second primer in the third exon region for the CNV and expression results comparisons. The primers of GBP6 and reference genes used for relative expression levels were listed in Table 1.

GBP6 (Chr3: 54,759,219-54,785,236)

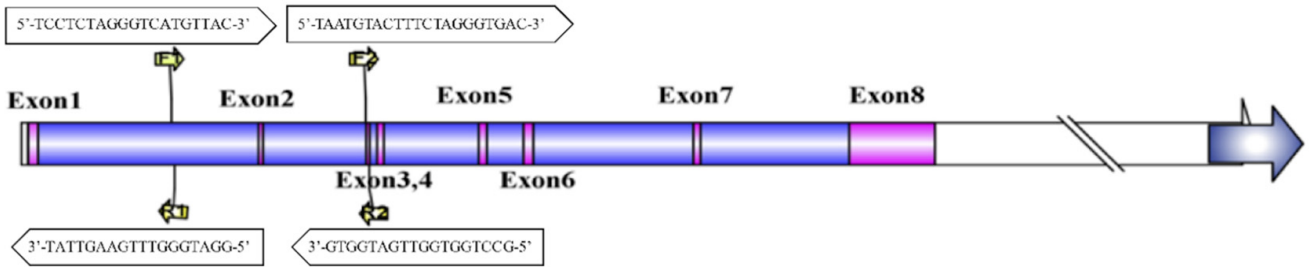

Figure 2. Two primers designed for quantitative polymerase chain reaction (qPCR) amplification on the gene structure of GBP6.

Table 1. Designed primers for real-time quantitative polymerase chain reaction (RT-qPCR) and qPCR based on Bos taurus genome of Bos_taurus_UMD_3.1 version.

\begin{tabular}{|c|c|c|}
\hline Gene & Pairs of Primer Sequence $\left(5^{\prime}-3^{\prime}\right)$ & Length (bp) \\
\hline GBP6 (1) & F-TCCTCTAGGGTCATGTTAC, R-GGATGGGTTTGAAGTTAT & 90 \\
\hline GBP6 (2) & F-TAATGTACTTTCTAGGGTGAC, R-GCCTGGTGGTTGATGGTG & 110 \\
\hline BTF3 & F-AACCAGGAGAAACTCGCCAA, R-TTCGGTGAAATGCCCTCTCG & 166 \\
\hline LRP10 & F-CCAGAGGATGAGGACGATGT, R-ATAGGGTTGCTGTCCCTGTG & 139 \\
\hline$E M D$ & F- GCCCTCAGCTTCACTCTCAGA, R- GAGGCGTTCCCGATCCTT & 100 \\
\hline
\end{tabular}

The amplification efficiencies of primers were tested by genomic DNA with PCR products concentration gradients that were 500, 100, 20, 4 and $0.8 \mathrm{ng}$. Afterward, $13 \mu \mathrm{L} 2 \times$ RealStar Green Power Mixture (GenStar, Beijing, China), $25 \mathrm{ng}$ extracted DNA or RNA, 10 pmol of primers and $9 \mu \mathrm{L} \mathrm{H}_{2} \mathrm{O}$ consisted of $25 \mu \mathrm{L}$ volume of the reaction mixture for the response system. The standard procedure for qPCR reaction was $95^{\circ} \mathrm{C}$ for $10 \mathrm{~min}$ followed by 40 cycles of $95^{\circ} \mathrm{C}$ for $15 \mathrm{~s}$ and $60^{\circ} \mathrm{C}$ for $1 \mathrm{~min}$. Additionally, the melting curve was added automatically by the CFX 96 TM Real-Time Detection System (Bio-Rad, Hercules, California, USA).

\subsection{Identification of $\mathrm{CNV}$ and Expression Levels for GBP6}

The relative CNV copy numbers were defined by an evaluation of $2 \times 2^{-\Delta \Delta C t}$ with the average threshold cycles $(\mathrm{Ct})$ in triplicate independent repeats, where $\Delta \mathrm{Ct}=\mathrm{Ct}_{\text {target gene }}-\mathrm{Ct}_{\text {reference gene }}$ following the previous studies [26,30,31,41-46]. The basic transcription factor 3 (BTF3) acted as the internal reference gene following the study of Bickhart et al. [43], because neither CNVs nor segmental duplications were observed in BTF3. Meanwhile, Angus cattle were treated as the reference sample for $\mathrm{CNV}$ identification. Moreover, $\mathrm{CNV}$ types were classified into three types that were gain type $\left(\log _{2} 2^{-\Delta \Delta C t} \geq 0.5\right)$, loss type $\left(\log _{2} 2^{-\Delta \Delta C t}<-0.5\right)$ and medium type $\left(-0.5 \leq \log _{2} 2^{-\Delta \Delta C t}<0.5\right)$, 
thus, $\log _{2} 2^{-\Delta \Delta C t}$ was considered as CNV type value [26,30,31,41-46]. Finally, the CNV results were summarized and displayed by Prism software (version 5.0.0). In the analysis of gene expression profiles, internal reference Emerin gene (EMD) and lipoprotein receptor-related protein 10 gene (LRP10) were used as reference internal genes for the expression level identifications following the study of Liu et al. [47] and Saremi et al. [48], respectively. The gene expression levels were also standardized by the $2^{-\Delta \Delta C t}$ method. Pearson correlation coefficient (PCC) of three replicates of tissue samples for gene expression levels was visualized by $\mathrm{R}$ package corrplot (version 0.84 ). The relative gene expression levels of different tissue samples were visualized in histograms by averaging three replicates.

\subsection{Statistical Analysis}

We used one-way analysis of variance (ANOVA) for all twelve phenotypes of NY, QC and XN cattle, separately, and two-way ANOVA for four common phenotypes of NY, QC and XN cattle together. Due to the commercial restrictions, cattle pedigree information was not available in six farms, so this study only applied the simple linear model rather than the linear mixed model considering the relationship matrix. The two models are:

$$
\begin{gathered}
\mathrm{Y}_{i}=\mu+\mathrm{CNV}_{i}+\mathrm{e}_{i}, \\
\mathrm{Y}_{i j}=\mu+\text { Breed }_{i}+\mathrm{CNV}_{j}+\text { Breed }_{i} \times \mathrm{CNV}_{j}+\mathrm{e}_{i j},
\end{gathered}
$$

where $\mathrm{Y}$ is the phenotype, $\mu$ is the overall mean, Breed is the breed of cattle (i.e., NY, QC and XN breed), $\mathrm{CNV}$ is the CNV type (i.e., gain, loss and medium), and e represents residual errors. Pairwise multiple comparisons for testing the mean differences between different breeds, CNV types and their interactions were based on Tukey's honestly significant difference (HSD) test [49].

\subsection{Bioinformatics Comparisons of GBP6 Associated with Growth Traits}

Based on the quantitative trait loci (QTLs) associated with growth traits of cattle along the whole Bos taurus genome (Bos_taurus_UMD_3.1), we investigated the density distribution of QTLs on different chromosomes. The QTL database was downloaded from Animal Quantitative Trait Loci Database (Animal QTLdb) for the growth traits of cattle (https://www.animalgenome.org/cgi-bin/ QTLdb/BT/traitmap?trait_ID=1449\&traitnm=Growth). Ten genes (CYP4A11, GBP2, GPC1, KCNJ12, KLF3, KLF6, LEPR, MAPK10, MICALL2 and MYH3) identified in relationship with growth traits by previous CNV studies [23-32] were used to overlap with QTL database on different chromosomes and to investigate the relationship between growth trait-related QTLs and ten CNV-related genes. The QTLs with candidate genes were visualized by R package RCircos (version 1.2.0) [50]. Furthermore, the identified candidate genes from all studies were analyzed in DAVID (Database for Annotation, Visualization and Integrated Discovery) Bioinformatics Resources 6.8 (https://david.ncifcrf.gov/) to achieve significant pathways $(p<0.05)$.

\section{Results}

\subsection{Animal Phenotypes}

Due to the commercial limitations, not all the phenotypes for $\mathrm{NY}, \mathrm{QC}$ and $\mathrm{XN}$ cattle were measured. Five phenotypes $(\mathrm{BoH}, \mathrm{BoL}, \mathrm{BoW}, \mathrm{ChC}$ and $\mathrm{HuW})$ for $\mathrm{NY}$ cattle, ten phenotypes $\mathrm{BoH}, \mathrm{BoL}, \mathrm{BoW}, \mathrm{ChC}$, $\mathrm{ChD}, \mathrm{ChW}, \mathrm{CrH}, \mathrm{HuW}, \mathrm{RuL}$ and $\mathrm{WaL})$ for $\mathrm{QC}$ cattle and seven phenotypes $(\mathrm{BoH}, \mathrm{BoL}, \mathrm{BoW}, \mathrm{CaC}, \mathrm{ChC}$, $\mathrm{CrH}$, and $\mathrm{WaC}$ ) for $\mathrm{XN}$ cattle were collected in this study (Table 2). From the average values of four phenotypes (BoH, BoL, BoW and $\mathrm{ChC}$ ) among NY, QC and $\mathrm{XN}$ cattle, we found that $\mathrm{XN}$ cattle had greater average body and chest size than NY and QC cattle, while NY and QC cattle showed similar performances (Table 2). 
Table 2. Statistics of Nanyang (NY), Qinchuan (QC) and Xianan (XN) cattle for twelve phenotypes.

\begin{tabular}{cccc}
\hline \multirow{2}{*}{ Phenotype } & \multicolumn{3}{c}{ Mean \pm SE (Cattle Number) } \\
\cline { 2 - 4 } & NY (112) & QC (105) & XN (213) \\
\hline BoH $(\mathrm{cm})$ & $126.81 \pm 0.60(58)$ & $129.42 \pm 0.58(95)$ & $135.52 \pm 0.33(198)$ \\
BoL $(\mathrm{cm})$ & $136.90 \pm 0.89(58)$ & $137.39 \pm 0.77(95)$ & $158.93 \pm 0.51(198)$ \\
BoW $(\mathrm{kg})$ & $373.10 \pm 5.52(58)$ & $395.31 \pm 6.17(95)$ & $548.88 \pm 3.93(198)$ \\
CaC $(\mathrm{cm})$ & 0 & 0 & $19.62 \pm 0.13(198)$ \\
ChC $(\mathrm{cm})$ & $169.67 \pm 1.21(58)$ & $175.70 \pm 1.01(95)$ & $193.68 \pm 0.64(198)$ \\
ChD $(\mathrm{cm})$ & 0 & $62.03 \pm 0.47(95)$ & 0 \\
ChW $(\mathrm{cm})$ & 0 & $37.62 \pm 0.46(95)$ & 0 \\
CrH $(\mathrm{cm})$ & 0 & $126.76 \pm 0.59(95)$ & $138.59 \pm 0.28(198)$ \\
HuW $(\mathrm{cm})$ & $25.86 \pm 0.27(58)$ & $22.42 \pm 0.43(95)$ & 0 \\
RuL $(\mathrm{cm})$ & 0 & $43.93 \pm 0.29(95)$ & 0 \\
WaL $(\mathrm{cm})$ & 0 & $42.40 \pm 0.35(95)$ & 0 \\
WaC $(\mathrm{cm})$ & 0 & 0 & $215.42 \pm 1.45(167)$ \\
\hline
\end{tabular}

Note: SE: standard error; NY: Nanyang breed; OC: Qinchuan breed; XN: Xianan breed; BoH: body height; BoL: body length; BoW: body weight; $\mathrm{CaC}$ : cannon circumference; $\mathrm{ChC}$ : chest circumference; $\mathrm{ChD}$ : chest depth; ChW: chest width; $\mathrm{CrH}$ : cross height; HuW: hucklebone width; RuL: rump length; WaC: waist circumference; WaL: waist length.

\subsection{Distributions of the CNV in Six Breeds}

We detected the copy number of GBP6 in six breeds, in which 213 XN cattle, 112 NY cattle, 105 QC cattle, $32 \mathrm{DN}$ cattle, $32 \mathrm{XJ}$ cattle, and $30 \mathrm{ZS}$ cattle were involved (Figure $3 \mathrm{a}$ ). The $\mathrm{CNV}$ distributions were mainly close to zero, and the $\mathrm{CNV}$ distributions of $\mathrm{XN}$ cattle and $\mathrm{ZS}$ cattle were significantly different from NY cattle (adjusted $p<0.05$ ) according to Student's $t$-test after multiple testing correction using false discovery rate (FDR) (Figure 3a). Interestingly, XN cattle, ZS cattle and NY cattle are from three different regions where the average temperatures and precipitations are $14.9{ }^{\circ} \mathrm{C}$ and $979.2 \mathrm{~mm}, 9.2{ }^{\circ} \mathrm{C}$ and $527.9 \mathrm{~mm}$ and $14.9^{\circ} \mathrm{C}$ and $777.7 \mathrm{~mm}$, respectively (Figure 1). However, no significant difference of $\mathrm{CNV}$ distribution was observed among DN, NY, XJ cattle that are from neighboring regions with the same average temperature $\left(14.9^{\circ} \mathrm{C}\right)$ and precipitation $(777.7 \mathrm{~m})$ (Figure 1). After the identification of three CNV types, 174, 245 and 105 cattle displayed gain, medium and loss CNV types, respectively (Figure 3b). Most of NY and QC cattle exhibited the medium CNV type, whereas more gain CNV types than loss and medium $\mathrm{CNV}$ types were presented in $\mathrm{XN}$ cattle (Figure 3c). The frequency of relative CNV copy number increased and then decreased at the peak of two, as a result of most of relative CNV copy number was two (Figure 3d). Additionally, XN cattle has 40.65\% (213/524) individuals of the whole analyzed samples, so it influenced the distribution of relative CNV copy numbers mostly, followed by NY cattle (112/524) and QC cattle (105/524) (Figure 3d). 
a

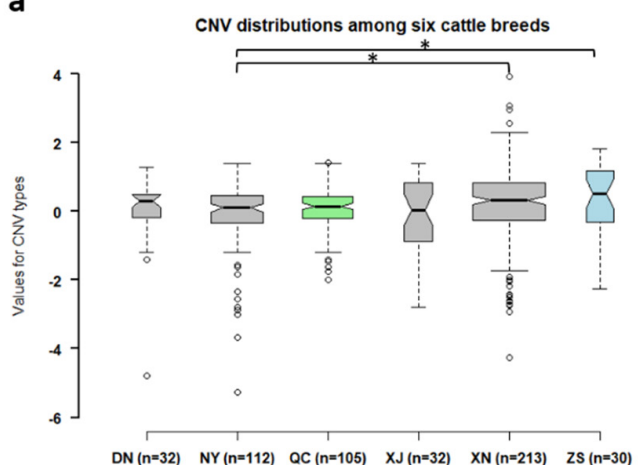

C

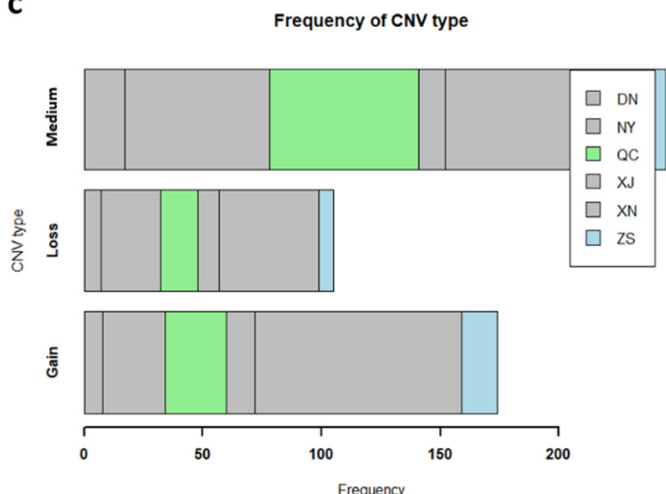

b

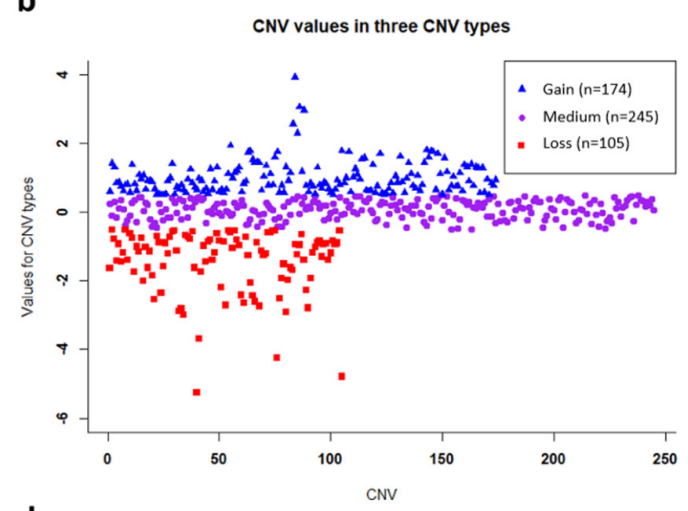

d

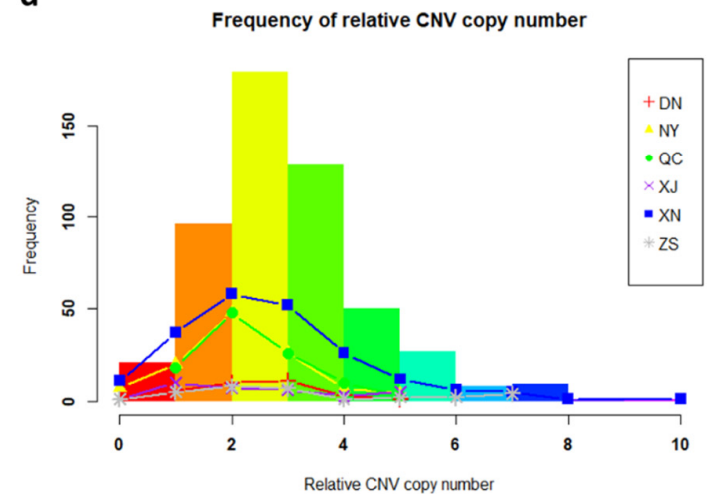

Figure 3. Copy number variations (CNVs) of GBP6. Note: SE: standard error; DN: Denan breed; NY: Nanyang breed; QC: Qinchuan breed; XJ: Xiajia breed; XN: Xianan breed; ZS: Zaosheng breed. (a) The distributions and statistics of CNV type values of GBP6 among six cattle breeds. Note: * indicates adjusted $P$ value $<0.05$ according to Student's $t$-test after multiple testing correction using false discovery rate (FDR). (b) Scatter plots of CNV type values in three CNV types (i.e., gain, medium and loss). (c) Frequencies of animals in three CNV types (i.e., gain, medium and loss) among six cattle breeds. (d) Frequencies of relative CNV copy number among six cattle breeds.

\subsection{Identified CNV Types of GBP6 Gene Associated with Growth Traits}

Among NY, QC and XN cattle, the association analysis revealed that three phenotypes (i.e., BoW, $\mathrm{CaC}$ and $\mathrm{ChC}$ ) of $\mathrm{XN}$ cattle performed significantly different across three different $\mathrm{CNV}$ types based on one-way ANOVA $(p<0.05)$ (Table 3). The results also showed that phenotypic values of $\mathrm{BoW}, \mathrm{CaC}$ and $\mathrm{ChC}$ of $\mathrm{XN}$ cattle increased accordingly, when the CNV types were from loss to gain, especially for $\mathrm{CaC}$ trait with the significant phenotypic differences in different $\mathrm{CNV}$ types after pairwise comparisons $(p<0.01)$. Based on the two-way ANOVA, breed effects were significant for all four phenotypes $(\mathrm{BoH}$, BoL, BoW and $\mathrm{ChC})(p<0.001)$, while CNV type and CNV type $\mathrm{x}$ breed interaction effects were not significant $(p>0.05)$ for these four phenotypes (Table 4 ). 
Table 3. Association results of one-way ANOVA for phenotypes of NY, QC and XN cattle.

\begin{tabular}{|c|c|c|c|c|c|}
\hline \multirow{2}{*}{ Breed } & \multirow{2}{*}{ Phenotype } & \multicolumn{3}{|c|}{ CNV type (Mean \pm SE) } & \multirow{2}{*}{$p$-Value } \\
\hline & & Loss & Medium & Gain & \\
\hline NY & $\mathrm{BoH}(\mathrm{cm})$ & $126.59 \pm 0.51$ & $126.96 \pm 0.61$ & $126.58 \pm 0.71$ & 0.96 \\
\hline NY & $\mathrm{BoL}(\mathrm{cm})$ & $137.95 \pm 0.73$ & $136.89 \pm 0.91$ & $135.96 \pm 1.03$ & 0.79 \\
\hline NY & BoW $(\mathrm{cm})$ & $381.00 \pm 2.77$ & $376.71 \pm 5.57$ & $355.33 \pm 6.88$ & 0.25 \\
\hline NY & $\mathrm{ChC}(\mathrm{cm})$ & $171.27 \pm 0.98$ & $169.87 \pm 1.16$ & $167.62 \pm 1.58$ & 0.64 \\
\hline NY & $\mathrm{HuW}(\mathrm{cm})$ & $25.77 \pm 0.30$ & $26.06 \pm 0.26$ & $25.38 \pm 0.32$ & 0.63 \\
\hline QC & $\mathrm{BoH}(\mathrm{cm})$ & $129.12 \pm 0.55$ & $129.75 \pm 0.62$ & $128.83 \pm 0.50$ & 0.79 \\
\hline$\hat{\mathrm{QC}}$ & $\mathrm{BoL}(\mathrm{cm})$ & $139.19 \pm 0.80$ & $136.71 \pm 0.78$ & $137.78 \pm 0.75$ & 0.50 \\
\hline QC & BoW(kg) & $405.50 \pm 6.03$ & $388.07 \pm 5.78$ & $405.84 \pm 7.13$ & 0.38 \\
\hline QC & $\mathrm{ChC}(\mathrm{cm})$ & $176.88 \pm 0.91$ & $174.58 \pm 0.97$ & $177.61 \pm 1.17$ & 0.41 \\
\hline $\mathrm{QC}$ & $\mathrm{ChD}(\mathrm{cm})$ & $61.75 \pm 0.55$ & $61.89 \pm 0.43$ & $62.57 \pm 0.53$ & 0.82 \\
\hline QC & $\mathrm{ChW}(\mathrm{cm})$ & $38.19 \pm 0.47$ & $37.22 \pm 0.47$ & $38.17 \pm 0.45$ & 0.60 \\
\hline QC & $\mathrm{CrH}(\mathrm{cm})$ & $126.69 \pm 0.53$ & $126.82 \pm 0.63$ & $126.67 \pm 0.55$ & 0.99 \\
\hline QC & $\mathrm{HuW}(\mathrm{cm})$ & $22.69 \pm 0.38$ & $22.04 \pm 0.44$ & $23.15 \pm 0.44$ & 0.54 \\
\hline QC & $\mathrm{RuL}(\mathrm{cm})$ & $44.12 \pm 0.28$ & $43.77 \pm 0.33$ & $44.17 \pm 0.22$ & 0.82 \\
\hline QC & WaL(cm) & $43.12 \pm 0.26$ & $41.89 \pm 0.35$ & $43.13 \pm 0.40$ & 0.22 \\
\hline $\mathrm{XN}$ & $\mathrm{BoH}(\mathrm{cm})$ & $134.29 \pm 0.46$ & $135.61 \pm 0.54$ & $136.06 \pm 0.40$ & 0.13 \\
\hline $\mathrm{XN}$ & $\mathrm{BoL}(\mathrm{cm})$ & $157.39 \pm 0.64$ & $159.24 \pm 0.88$ & $159.42 \pm 0.61$ & 0.30 \\
\hline $\mathrm{XN}$ & BoW $(k g)$ & $531.59 \pm 3.69^{a}$ & $548.97 \pm 4.01^{\mathrm{ab}}$ & $557.56 \pm 3.86^{b}$ & 0.04 \\
\hline $\mathrm{XN}$ & $\mathrm{CaC}(\mathrm{cm})$ & $18.89 \pm 0.10^{\mathrm{Aa}}$ & $19.70 \pm 0.12^{b}$ & $19.93 \pm 0.14^{\mathrm{B}}$ & 0.01 \\
\hline $\mathrm{XN}$ & $\mathrm{ChC}(\mathrm{cm})$ & $189.93 \pm 0.65^{\mathrm{a}}$ & $194.70 \pm 0.58^{b}$ & $194.62 \pm 0.66^{b}$ & 0.01 \\
\hline $\mathrm{XN}$ & $\mathrm{CrH}(\mathrm{cm})$ & $137.88 \pm 0.24$ & $138.92 \pm 0.34$ & $138.63 \pm 0.23$ & 0.40 \\
\hline $\mathrm{XN}$ & $\mathrm{WaC}(\mathrm{cm})$ & $212.10 \pm 1.32$ & $216.03 \pm 1.28$ & $216.79 \pm 1.39$ & 0.44 \\
\hline
\end{tabular}

Note: SE: standard error; NY: Nanyang breed; QC: Qinchuan breed; XN: Xianan breed; BoH: body height; BoL: body length; BoW: body weight; CaC: cannon circumference; $\mathrm{ChC}$ : chest circumference; $\mathrm{ChD}$ : chest depth; ChW: chest width; $\mathrm{CrH}$ : cross height; HuW: hucklebone width; RuL: rump length; WaC: waist circumference; WaL: waist length. ${ }^{\mathrm{ab} / \mathrm{AB}}$ refers to significant difference after multiple pairwise comparisons $(p<0.05 / 0.01)$.

Table 4. $p$-Value results of two-way ANOVA for four phenotypes of NY, QC and XN cattle.

\begin{tabular}{|c|c|c|c|c|c|c|c|c|c|c|c|c|}
\hline Fixed Effect & \multicolumn{3}{|c|}{ BoH } & \multicolumn{3}{|c|}{ BoL } & \multicolumn{3}{|c|}{ BoW } & \multicolumn{3}{|c|}{$\mathrm{ChC}$} \\
\hline \multirow[b]{2}{*}{ Breed } & & $<0.001$ & & & $<0.001$ & & & $<0.001$ & & & $<0.001$ & \\
\hline & A NY & ${ }^{\mathrm{AB}} \mathrm{QC}$ & ${ }^{\mathrm{B}} \mathrm{XN}$ & ${ }^{\mathrm{A}} \mathrm{NY}$ & ${ }^{\mathrm{A}} \mathrm{QC}$ & ${ }^{\mathrm{B}} \mathrm{XN}$ & ${ }^{\mathrm{a}} \mathrm{NY}$ & ${ }^{\mathrm{Ab}} \mathrm{QC}$ & ${ }^{\mathrm{B}} \mathrm{XN}$ & ${ }^{\mathrm{A}} \mathrm{NY}$ & ${ }^{\mathrm{AB}} \mathrm{QC}$ & ${ }^{\mathrm{B}} \mathrm{XN}$ \\
\hline CNV type & & 0.29 & & & 0.81 & & & 0.25 & & & 0.19 & \\
\hline Breed $\times$ CNV type & & 0.78 & & & 0.42 & & & 0.12 & & & 0.09 & \\
\hline
\end{tabular}

Note: ${ }^{\mathrm{ab} / \mathrm{AB}}$ refers to significant difference after multiple pairwise comparisons $(p<0.05 / 0.01)$. NY: Nanyang breed; QC: Qinchuan breed; XN: Xianan breed; BoH: body height; BoL: body length; BoW: body weight; ChC: chest circumference.

\subsection{Gene Expression Levels of GBP6}

Three replicates of relative expression levels of GBP6 showed high repeatability of the measurements with PCC values above $0.9(p<0.001)$ both in QC adults and XN adults (Figure 4a3,a4). However, the PCC values for three replicates of relative expression levels of GBP6 were above 0.7 in QC fetuses (Figure 4a1) and lower than 0.5 in QC calves that showed poor repeatability of the measurements (Figure 4a2). Generally, tissue samples from spleen of QC and XN adults had higher relative expression levels than those from other tissues (Figure 4b). In the same stages, we used heart expressions as the control to compare with other tissue expressions. The results also showed that GBP6 was significantly expressed in the muscle $(p<0.05)$ and spleen $(p<0.001)$ of $Q C$ fetuses, in the liver $(p<0.001)$ of QC calves, in the kidney $(p<0.01)$, liver $(p<0.01)$, muscle $(p<0.001)$ and spleen $(p<0.01)$ of QC adults, and in the liver $(p<0.05)$ and muscle $(p<0.001)$ of XN adults. In addition, GBP6 was significantly expressed in the heart among three stages $(p<0.001)$, in the spleen, muscle and fat between fetal and adult stages $(p<0.05)$, and in the spleen between calf and adult stages $(p<0.05)$ of QC cattle after Student's t-test (Figure 4b). Moreover, GBP6 was significantly expressed in the heart $(p<0.05)$, kidney $(p<0.05)$ and lung $(p<0.01)$ of adult stage between QC and XN cattle (Figure $4 b)$. 
The transcription levels of GBP6 of longissimus dorsi muscle from XN cattle among three CNV types were strongly associated with growth traits (e.g., Cannon circumference $(\mathrm{CaC})$ and body weight $(\mathrm{BoW}))$ (Figure 4c). It was suggested that the gain CNV type of GBP6 displaying the highest relative expression levels and resulted in highest phenotypes that included $\mathrm{CaC}(19.93 \mathrm{~cm})$ and BoW $(557.56 \mathrm{~kg})$ (Figure 4c and Table 3). All of the relative expression values of GBP6 in seven tissues of QC and XN cattle in fetal, calf and adult stages with three replicates were listed in Table S1.

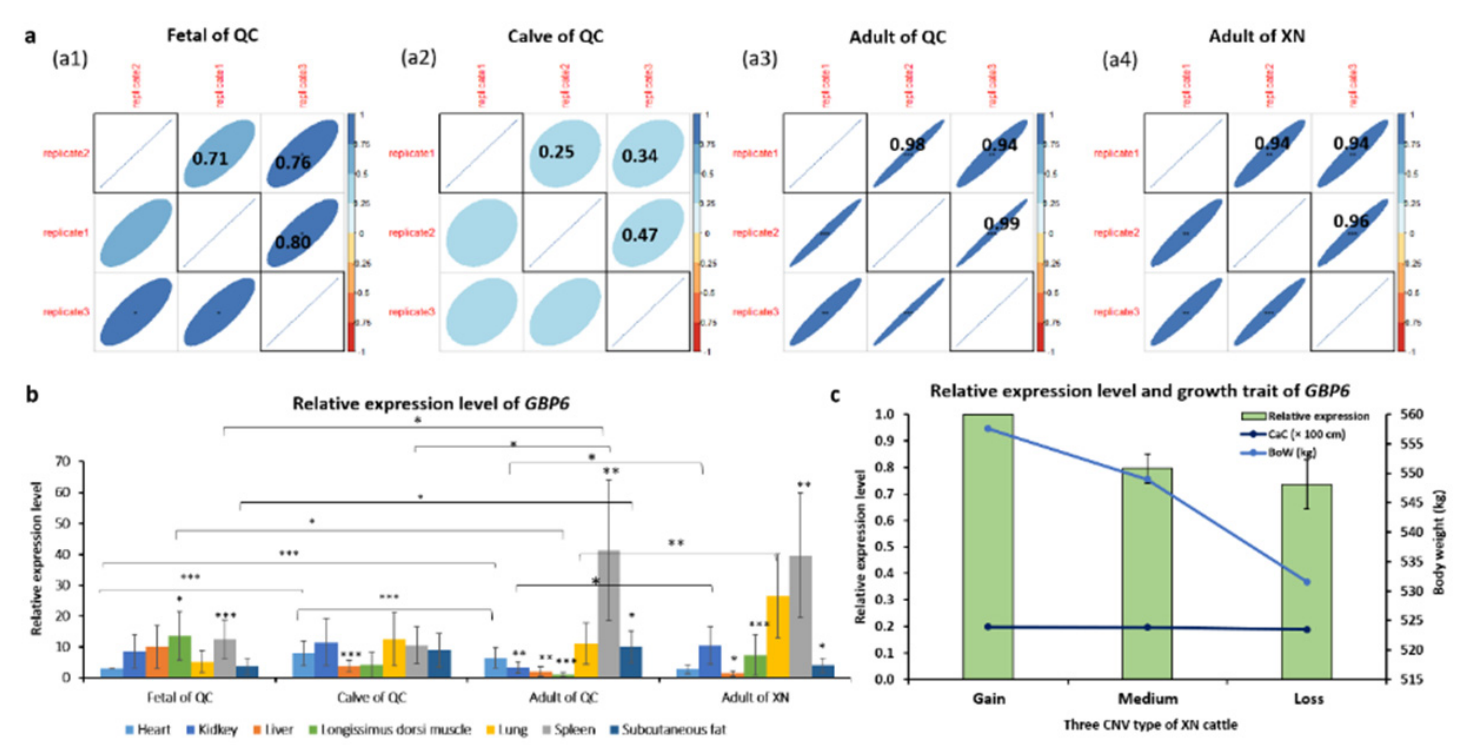

Figure 4. Relative gene expression levels of GBP6. Note: ${ }^{*}{ }^{* *}$ and ${ }^{* * *}$ indicates $p$ value $<0.05,<0.01$ and <0.001, respectively. QC: Qinchuan breed; XN: Xianan breed; CaC: Cannon circumference; BoW: body weight. (a) PCCs of three replicates of relative expression levels of QC fetuses (a1), QC calves (a2), QC adults (a3) and XN adults (a4). (b) Relative expression levels among seven tissues. (c) Relative expression levels of muscle tissues among three CNV types (i.e., gain, medium and loss) associated with growth traits of $\mathrm{XN}$ cattle. Note: Only BoW uses $y$-axis.

\subsection{Comparative Validation of GBP6 with other Studies Associated with Growth Traits}

The QTLs associated with growth traits of cattle were distributed on each chromosome and mainly concentrated on chromosome 6, 18 and 21. GBP6 was located on chromosome 3 with low QTL densities, but it probably collaborates with the neighboring GBP2 on affecting growth traits of cattle through potential strong linkage disequilibrium (LD) (Figure 5). Ten genes (CYP4A11, GBP2, GPC1, KCNJ12, KLF3, KLF6, LEPR, MAPK10, MICALL2 and MYH3) on five different chromosomes (i.e., 3, 6, 13, 19 and 25) from previous similar CNV studies [23-32] were used for the comparison of our results (Table 5). These candidate genes were mainly located on chromosome 3 and enriched in the Bos taurus 04920: Adipocytokine signaling pathway $(p<0.05)$. They were consistent with body size traits (e.g., height, length and weight) of Chinese cattle from different provinces, where three of them exhibited positive associations between expressions and CNV types (i.e., gain CNV type with highest expressions), but six of them exhibited negative associations (Table 5). 
Table 5. Identified candidate CNV-related genes associated with growth traits of cattle from other studies.

\begin{tabular}{|c|c|c|c|c|c|c|c|c|c|c|c|}
\hline \multirow[b]{2}{*}{ Genes } & \multirow[b]{2}{*}{ Chromosome } & \multirow[b]{2}{*}{ Position } & \multicolumn{5}{|c|}{ Growth Trait } & \multirow[b]{2}{*}{ Breed } & \multirow[b]{2}{*}{$\begin{array}{l}\text { Province } \\
\text { of China }\end{array}$} & \multirow{2}{*}{$\begin{array}{l}\text { Association of } \\
\text { CNV Type and } \\
\text { Expression }\end{array}$} & \multirow[b]{2}{*}{ Reference } \\
\hline & & & $\begin{array}{c}\text { Body } \\
\text { Height }\end{array}$ & $\begin{array}{c}\text { Body } \\
\text { Length }\end{array}$ & $\begin{array}{c}\text { Body } \\
\text { Weight }\end{array}$ & $\begin{array}{l}\text { Heart } \\
\text { Girth }\end{array}$ & $\begin{array}{l}\text { Chest } \\
\text { Girth }\end{array}$ & & & & \\
\hline CYP4A11 & 3 & $99,806,653-99,820,785$ & & & & $\checkmark$ & & Qinchuan & Shannxi & Positive & [23] \\
\hline CYP4A11 & 3 & $99,806,653-99,820,785$ & & $\checkmark$ & & & & Nanyang & Henan & Positive & [23] \\
\hline CYP4A11 & 3 & $99,806,653-99,820,785$ & & & $\checkmark$ & $\checkmark$ & & Jinnan & Jilin & Positive & [23] \\
\hline GBP2 & 3 & $54,345,493-54,437,452$ & $\checkmark$ & $\checkmark$ & & $\checkmark$ & & Pinan & Henan & & [24] \\
\hline GPC1 & 3 & $120,383,537-120,476,583$ & $\checkmark$ & $\checkmark$ & $\checkmark$ & $\checkmark$ & & Datong yak & Qinghai & Negative & [26] \\
\hline KCNJ12 & 19 & $35,955,260-35,993,796$ & & $\checkmark$ & $\checkmark$ & & & Guangfeng & Jiangxi & Negative & [27] \\
\hline KCNJ12 & 19 & $35,955,260-35,993,796$ & & $\checkmark$ & $\checkmark$ & & & Jiaxian Red & Henan & Negative & [27] \\
\hline KLF3 & 6 & $59,587,076-59,614,488$ & & & $\checkmark$ & $\checkmark$ & & Cattle & & Positive & [29] \\
\hline KLF6 & 13 & $44,945,030-44,952,166$ & $\checkmark$ & $\checkmark$ & $\checkmark$ & & $\checkmark$ & Datong yak & Qinghai & Negative & [25] \\
\hline$L E P R$ & 3 & $80,071,689-80,167,592$ & $\checkmark$ & $\checkmark$ & $\checkmark$ & & $\checkmark$ & Nanyang & Henan & Positive & [31] \\
\hline MAPK10 & 6 & $102,683,802-103,320,828$ & & $\checkmark$ & $\checkmark$ & $\checkmark$ & & Nanyang & Henan & Negative & [32] \\
\hline MICALL2 & 25 & $42,015,483-42,035,251$ & $\checkmark$ & & $\checkmark$ & & $\checkmark$ & Nanyang & Henan & Negative & [29] \\
\hline MYH3 & 19 & $30,230,160-30,251,091$ & $\checkmark$ & $\checkmark$ & $\checkmark$ & & & Nanyang & Henan & Negative & [30] \\
\hline
\end{tabular}

Note: Positive/Negative indicate the expressions increase/decrease from loss to gain CNV types. $\checkmark$ indicates the associated growth traits. 


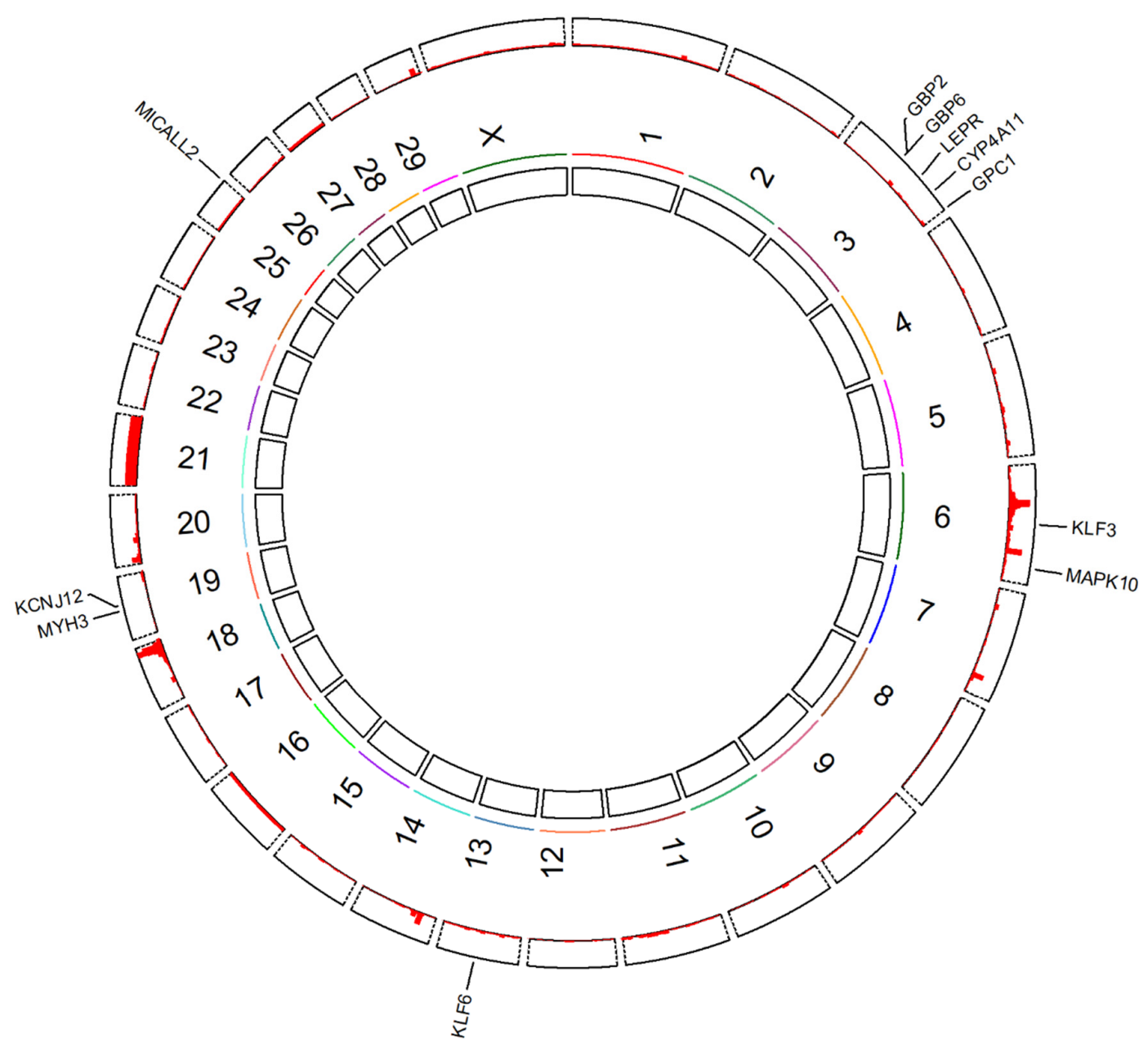

Figure 5. Circular graph of the densities of quantitative trait locis (QTLs) and identified candidate genes from other similar studies [23-32]. Note: the QTL densities in the red histogram were counted by 1 mega base pairs $(\mathrm{Mb})$ windows.

\section{Discussion}

\subsection{Domestic Beef Cattle in China}

The six cattle breeds (NY, QC, XN, DN, XJ and ZS) in this study were the important breeds for beef production in China, especially for XN cattle which is a relatively new Chinese breed since 2007, after introducing Charolais cattle as sire to crossbreed with NY cattle for more than two decades [51]. Based on the hybridization for inheriting the good meat production from Charolais cattle [52], XN cattle exhibited higher body size values than NY cattle in this study (Table 2). Moreover, breed effect results in the two-way ANOVA showed that $\mathrm{BoH}, \mathrm{Bol}, \mathrm{BoW}$ and $\mathrm{ChC}$ traits of $\mathrm{XN}$ cattle were significantly higher than NY and QC cattle $(p<0.001)$ (Table 4). Mostly, the current genome-wide association studies (GWAS) apply pedigree information to control the population structure [53] and to estimate polygenic effects for the increased statistical power [54]. It is suggested the mixed model for GWAS fits pedigree in the kinship coefficient matrix to capture the polygenic variance [55], while SNPs or $\mathrm{CNVs}$ are tested as the fixed effects. Unfortunately, due to the restrictions in the commercial farms, no available pedigree data could be applied in this study; hence, the random variance accounting for the polygenic effects cannot be estimated. 


\subsection{The CNV Distributions with Biological Features of GBP6}

The CNV distributions of GBP6 revealed that the frequencies of three CNV types varied among six cattle breeds, especially for $\mathrm{XN}$ cattle owning more gain $\mathrm{CNV}$ type than the other cattle breeds (Figure 3 ). The results are consistent with the study of Shi et al. [31] that XN cattle also presented more gain copy number of LEPR. In one cattle species, CNV distribution could appear as an independent pattern, so the $\mathrm{CNV}$ copy number frequencies are different across diverse breeds [46]. As the crossbreed of Charolais and NY cattle, $\mathrm{XN}$ cattle tended to arise independent $\mathrm{CNV}$ patterns after a period of domestication for the breed formation. GBP6 is an immune-related gene, which is located on chromosome 3 along with other four family members that are GBP1 (54306891-54323003), GBP2 (54345493-54437452), GBP4 (54627197-54683058) and GBP5 (54252901-54269516). The neighboring GBP genes are found to be located in the growth trait-related QTL regions (Figure 5), in which GBP2 and GBP4 within particular CNVRs that were associated with growth traits of Chinese cattle [24,36]. Interestingly, LEPR, CYP4A11 and GPC1 are also located on chromosome 3, so CNVs of these genes on the same chromosome are probably still in LD with a QTL because LD could exist at long distances [56].

\subsection{The Identified CNVs and Expression Levels of GBP6 Associated with Growth Traits}

The gain type of CNVs was reported in relationship with the increased body weight and chest size [27,31]. Our results also found that gain CNV type and highest body size traits (e.g., BoW, CaC and $\mathrm{ChC}$ ) of $\mathrm{XN}$ cattle were in consistency (Table 3). Overall, SVs like CNV can cause differences in gene expression levels, and then influence the phenotype subsequently [2]. For example, some genes affected by the CNVs can change the copy-number to overlap or to disrupt the structure, and subsequently alter gene dosage in the genome [57]. Among one single gene, the insertions or deletions of CNVs directly influence the frameshifts, non-frameshift mutations and splice variants in the coding exon region. Additionally, the intron sequences can be affected by CNVs to result in alternative splicing [58].

Most importantly, the CNVs in cattle were also suggested to influence the genes for specific biological functions (e.g., immunity, rumination and reproduction) [46]. In addition, Stranger et al. [59] demonstrated that $17.7 \%$ of the total detected genetic variations in gene expression could be explained by $\mathrm{CNVs}$, and the positive associations between CNVs and gene expressions were also observed in several studies $[23,29,31,59,60]$. In this study, the gain type of CNV might contribute GBP6 expression levels to the highest in muscle tissues (Figure 4c); therefore, high expressions boosted the advantageous growth traits such as $\mathrm{CaC}$ and BoW. Transcriptome levels of GBP6 varied significantly $(p<0.001)$ in different developmental stages and different tissues in the current study (Figure $4 b$ ), which indicated GBP6 plays different important roles in the whole growth developments of cattle. By the combination of GWAS and global gene expression, the expression quantitative trait loci (eQTLs) study can identify QTLs that explain fractions of variation in the expression levels [61]. For example, QTLs associated with growth traits (Figure 5) can be used for eQTLs analysis by combining expression level of longissimus dorsi muscle with QTLs. In order to clearly define the presence of CNVs at genomic level influencing genome-wide gene expression levels related to the phenotypes on an individual, eQTLs analysis using CNVs could provide better understanding of basic genetic mechanism of gene expressions underlying growth traits [62].

\section{Conclusions}

Our study identified the CNV distributions of GBP6 among six beef cattle breeds in China, and associated CNV types and gene expression levels with growth traits in XN, QC and NY cattle. Results showed that the CNV distributions varies among different cattle breeds and expression levels varies across different stages and different tissues of different breeds. Statistical analysis revealed that the CNV types were consistent with expression levels of GBP6 and subsequently influenced the growth traits. It was suggested that GBP6 could be applied in the breeding program for growth traits by including gain types of $\mathrm{CNV}$. 
Supplementary Materials: The following are available online at http://www.mdpi.com/2076-2615/10/4/566/s1, Table S1: Relative expression values of GBP6 in seven tissues of QC and XN cattle in fetal, calve and adult stages with three replicates.

Author Contributions: D.H. performed all the experiments; X.W. (Xiao Wang) and D.H. analyzed the data and wrote the manuscript; X.W. (Xiao Wang), B.T. and H.N.K. improved the manuscript; X.W. (Xiaogang Wang), X.L., Y.H. and X.Q. collected the animal samples; H.C. conceived and designed the experiments. All authors read and approved the final manuscript.

Funding: This research received no external funding.

Acknowledgments: This work was supported by the National Natural Science Foundation of China (No.31772574) the Program of National Beef Cattle and Yak Industrial Technology System (CARS-37), Bio-breeding capacity-building and industry specific projects from National Development and Reform Commission (2014-2573), Specific Projects of Science and Technology in Henan Province (141100110200). Dan Hao and Xiao Wang appreciated the scholarship from the China Scholarship Council (CSC), China.

Conflicts of Interest: The authors declare that they have no conflict of interest.

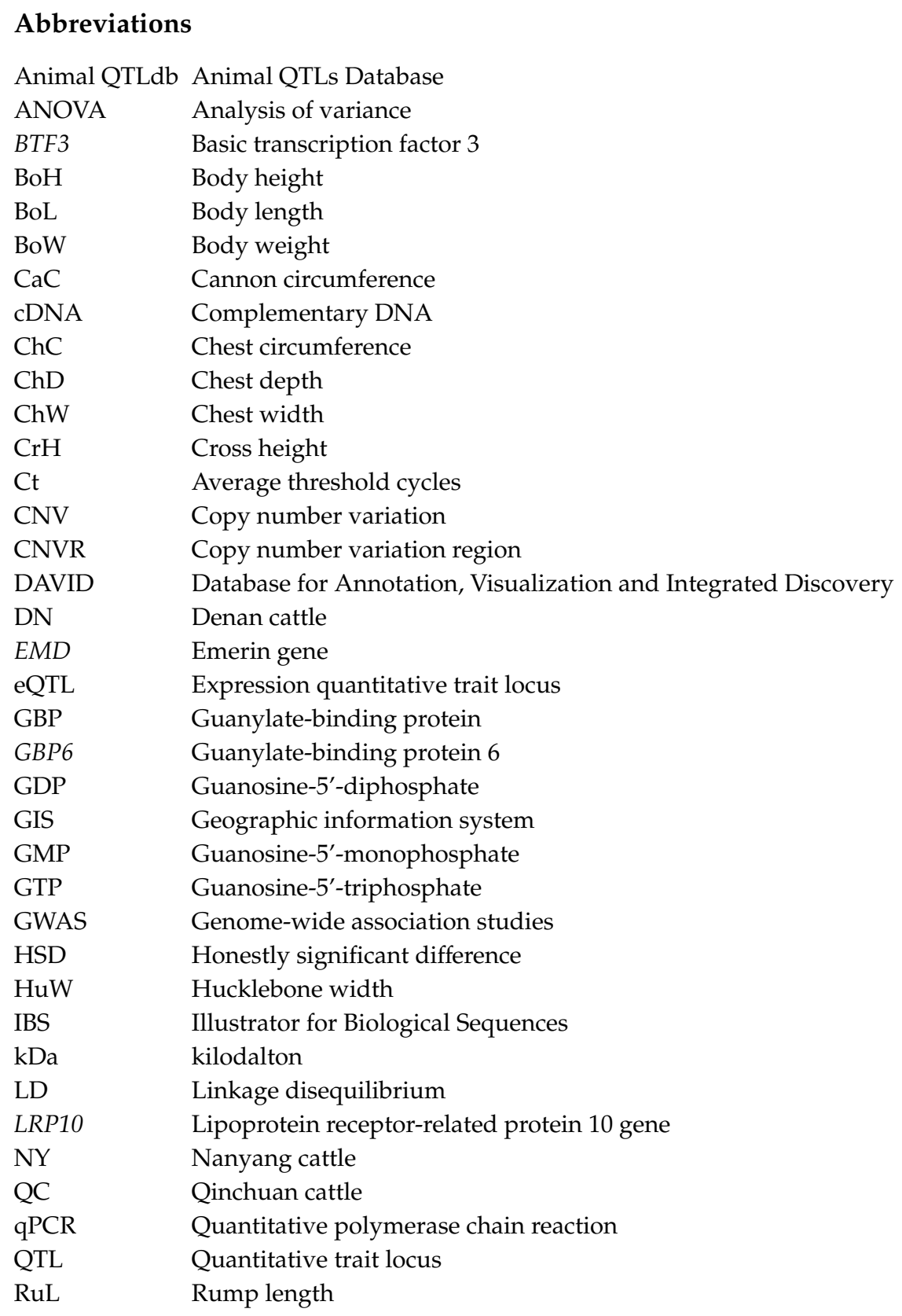




$\begin{array}{ll}\text { SNP } & \text { Single nucleotide polymorphism } \\ \text { SV } & \text { Structural variation } \\ \text { WaC } & \text { Waist circumference } \\ \text { WaL } & \text { Waist length } \\ \text { XJ } & \text { Xiajia cattle } \\ \text { XN } & \text { Xianan cattle } \\ \text { ZS } & \text { Zaosheng cattle }\end{array}$

\section{References}

1. Abyzov, A.; Li, S.; Gerstein, M.B. Understanding genome structural variations. Oncotarget 2016, 7, 7370-7371. [CrossRef] [PubMed]

2. Feuk, L.; Carson, A.R.; Scherer, S.W. Structural variation in the human genome. Nat. Rev. Genet. 2006, 7, 85-97. [CrossRef]

3. Redon, R.; Ishikawa, S.; Fitch, K.R.; Feuk, L.; Perry, G.H.; Andrews, T.D.; Fiegler, H.; Shapero, M.H.; Carson, A.R.; Chen, W.; et al. Global variation in copy number in the human genome. Nature 2006, 444, 444-454. [CrossRef] [PubMed]

4. Ragoussis, J. Genotyping Technologies for Genetic Research. Annu. Rev. Genom. Hum. Genet. 2009, 10, 117-133. [CrossRef] [PubMed]

5. Altshuler, D.M.; Durbin, R.M.; Abecasis, G.R.; Bentley, D.R.; Chakravarti, A.; Clark, A.G.; Donnelly, P.; Eichler, E.E.; Flicek, P.; Gabriel, S.B.; et al. An integrated map of genetic variation from 1092 human genomes. Nature 2012, 491, 56-65.

6. Belmont, J.W.; Boudreau, A.; Leal, S.M.; Hardenbol, P.; Pasternak, S.; Wheeler, D.A.; Willis, T.D.; Yu, F.; Yang, H.; Gao, Y.; et al. A haplotype map of the human genome. Nature 2005, 437, 1299-1320.

7. Malhotra, D.; McCarthy, S.; Michaelson, J.J.; Vacic, V.; Burdick, K.E.; Yoon, S.; Cichon, S.; Corvin, A.; Gary, S.; Gershon, E.S.; et al. High frequencies of de novo cnvs in bipolar disorder and schizophrenia. Neuron 2011, 72, 951-963. [CrossRef]

8. Marshall, C.R.; Scherer, S.W. Detection and characterization of copy number variation in autism spectrum disorder. Methods Mol. Biol. 2011, 838, 115-135.

9. Dauber, A.; Yu, Y.; Turchin, M.C.; Chiang, C.W.; Meng, Y.A.; Demerath, E.W.; Patel, S.R.; Rich, S.S.; Rotter, J.I.; Schreiner, P.J.; et al. Genome-wide association of copy-number variation reveals an association between short stature and the presence of low-frequency genomic deletions. Am. J. Hum. Genet. 2011, 89, 751-759. [CrossRef]

10. Wang, X.; Byers, S. Copy Number Variation in Chickens: A Review and Future Prospects. Microarrays 2014, 3, 24-38. [CrossRef]

11. Yang, L.; Xu, L.; Zhou, Y.; Liu, M.; Wang, L.; Kijas, J.W.; Zhang, H.; Li, L.; Liu, G.E. Diversity of copy number variation in a worldwide population of sheep. Genomics 2018, 110, 143-148. [CrossRef] [PubMed]

12. Fadista, J.; Nygaard, M.; Holm, L.E.; Thomsen, B.; Bendixen, C. A snapshot of CNVs in the pig genome. PLOS ONE 2008, 3, e3916. [CrossRef] [PubMed]

13. Chen, C.; Qiao, R.; Wei, R.; Guo, Y.; Ai, H.; Ma, J.; Ren, J.; Huang, L. A comprehensive survey of copy number variation in 18 diverse pig populations and identification of candidate copy number variable genes associated with complex traits. BMC Genom. 2012, 13, 733. [CrossRef] [PubMed]

14. Long, Y.; Su, Y.; Ai, H.; Zhang, Z.; Yang, B.; Ruan, G.; Xiao, S.; Liao, X.; Ren, J.; Huang, L.; et al. A genome-wide association study of copy number variations with umbilical hernia in swine. Anim. Genet. 2016, 47, $298-305$. [CrossRef]

15. Wang, L.; Xu, L.; Liu, X.; Zhang, T.; Li, N.; Hay, E.H.; Zhang, Y.; Yan, H.; Zhao, K.; Liu, G.E.; et al. Copy number variation-based genome wide association study reveals additional variants contributing to meat quality in Swine. Sci. Rep. 2015, 5, 12535. [CrossRef]

16. Revilla, M.; Puig-Oliveras, A.; Castelló, A.; Crespo-Piazuelo, D.; Paludo, E.; Fernández, A.I.; Ballester, M.; Folch, J.M. A global analysis of CNVs in swine using whole genome sequence data and association analysis with fatty acid composition and growth traits. PLoS ONE 2017, 12, e0177014. [CrossRef]

17. Prinsen, R.T.M.M.; Rossoni, A.; Gredler, B.; Bieber, A.; Bagnato, A.; Strillacci, M.G. A genome wide association study between CNVs and quantitative traits in Brown Swiss cattle. Livest. Sci. 2017, 202, 7-12. [CrossRef] 
18. Da Silva, V.H.; De Almeida Regitano, L.C.; Geistlinger, L.; Pértille, F.; Giachetto, P.F.; Brassaloti, R.A.; Morosini, N.S.; Zimmer, R.; Coutinho, L.L. Genome-wide detection of CNVs and their association with meat tenderness in Nelore cattle. PLoS ONE 2016, 11, e0157711. [CrossRef]

19. Upadhyay, M.; da Silva, V.H.; Megens, H.J.; Visker, M.H.P.W.; Ajmone-Marsan, P.; Bâlteanu, V.A.; Dunner, S.; Garcia, J.F.; Ginja, C.; Kantanen, J.; et al. Distribution and functionality of copy number variation across European cattle populations. Front. Genet. 2017, 8, 108. [CrossRef]

20. Zhou, Y.; Connor, E.E.; Wiggans, G.R.; Lu, Y.; Tempelman, R.J.; Schroeder, S.G.; Chen, H.; Liu, G.E. Genome-wide copy number variant analysis reveals variants associated with 10 diverse production traits in Holstein cattle. BMC Genom. 2018, 19, 314. [CrossRef]

21. Ben Sassi, N.; González-Recio, Ó.; de Paz-del Río, R.; Rodríguez-Ramilo, S.T.; Fernández, A.I. Associated effects of copy number variants on economically important traits in Spanish Holstein dairy cattle. J. Dairy Sci. 2016, 99, 6371-6380. [CrossRef] [PubMed]

22. Zhou, Y.; Utsunomiya, Y.T.; Xu, L.; abdel Hay, E.H.; Bickhart, D.M.; Alexandre, P.A.; Rosen, B.D.; Schroeder, S.G.; Carvalheiro, R.; de Rezende Neves, H.H.; et al. Genome-wide CNV analysis reveals variants associated with growth traits in Bos indicus. BMC Genom. 2016, 17, 419. [CrossRef] [PubMed]

23. Yang, M.; Lv, J.; Zhang, L.; Li, M.; Zhou, Y.; Lan, X.; Lei, C.; Chen, H. Association study and expression analysis of CYP4A11 gene copy number variation in Chinese cattle. Sci. Rep. 2017, 7, 46599. [CrossRef] [PubMed]

24. Zhang, G.M.; Zheng, L.; He, H.; Song, C.C.; Zhang, Z.J.; Cao, X.K.; Lei, C.Z.; Lan, X.Y.; Qi, X.L.; Chen, H.; et al. Associations of GBP2 gene copy number variations with growth traits and transcriptional expression in Chinese cattle. Gene 2018, 647, 101-106. [CrossRef] [PubMed]

25. Goshu, H.A.; Wu, X.; Chu, M.; Bao, P.; Ding, X.; Yan, P. Copy number variations of KLF6 modulate gene transcription and growth traits in chinese datong yak (Bos grunniens). Animals 2018, 8, 145. [CrossRef] [PubMed]

26. Goshu, H.A.; Chu, M.; Wu, X.; Pengjia, B.; Ding, X.Z.; Yan, P. Association study and expression analysis of GPC1 gene copy number variation in Chinese Datong yak (Bos grunniens) breed. Ital. J. Anim. Sci. 2019, 18, 820-832. [CrossRef]

27. Zheng, L.; Xu, J.W.; Li, J.C.; Wang, D.H.; An, Q.M.; Xu, L.N.; Ma, Y.L.; Wang, J.; Peng, S.J.; Lei, C.Z.; et al. Distribution and association study in copy number variation of KCNJ12 gene across four Chinese cattle populations. Gene 2019, 689, 90-96. [CrossRef]

28. Xu, J.W.; Zheng, L.; Li, L.J.; Yao, Y.F.; Hua, H.; Yang, S.Z.; Wen, Y.F.; Song, C.C.; Cao, X.K.; Liu, K.P.; et al. Novel copy number variation of the KLF3 gene is associated with growth traits in beef cattle. Gene 2019, 680, 99-104. [CrossRef]

29. Xu, Y.; Zhang, L.; Shi, T.; Zhou, Y.; Cai, H.; Lan, X.; Zhang, C.; Lei, C.; Chen, H. Copy number variations of MICAL-L2 shaping gene expression contribute to different phenotypes of cattle. Mamm. Genome 2013, 24, 508-516. [CrossRef]

30. Xu, Y.; Shi, T.; Cai, H.; Zhou, Y.; Lan, X.; Zhang, C.; Lei, C.; Qi, X.; Chen, H. Associations of MYH3 gene copy number variations with transcriptional expression and growth traits in chinese cattle. Gene 2014, 535, 106-111. [CrossRef]

31. Shi, T.; Xu, Y.; Yang, M.; Huang, Y.; Lan, X.; Lei, C.; Qi, X.; Yang, X.; Chen, H. Copy number variations at LEPR gene locus associated with gene expression and phenotypic traits in Chinese cattle. Anim. Sci. J. 2015, 87, 336-343. [CrossRef] [PubMed]

32. Liu, M.; Li, B.; Huang, Y.; Yang, M.; Lan, X.; Lei, C.; Qu, W.; Bai, Y.; Chen, H. Copy number variation of bovine MAPK10 modulates the transcriptional activity and affects growth traits. Livest. Sci. 2016, 194, 44-50. [CrossRef]

33. Schwemmlel, M.; Staeheli, P. The interferon-induced 67-kDa guanylate-binding protein (hGBP1) is a GTPase that converts GTP to GMP. J. Biol. Chem. 1994, 269, 11299-11305.

34. Wennerberg, K.; Rossman, K.L.; Der, C.J. The Ras superfamily at a glance. J. Cell Sci. 2005, 118, 843-846. [CrossRef] [PubMed]

35. Ngo, C.C.; Man, S.M. Mechanisms and functions of guanylate-binding proteins and related interferon-inducible GTPases: Roles in intracellular lysis of pathogens. Cell. Microbiol. 2017, 19, e12791. [CrossRef] [PubMed] 
36. Cao, X.K.; Huang, Y.Z.; Ma, Y.L.; Cheng, J.; Qu, Z.X.; Ma, Y.; Bai, Y.Y.; Tian, F.; Lin, F.P.; Ma, Y.L.; et al. Integrating CNVs into meta-QTL identified GBP4 as positional candidate for adult cattle stature. Funct. Integr. Genom. 2018, 18, 559-567. [CrossRef]

37. Zhang, L.; Jia, S.; Yang, M.; Xu, Y.; Li, C.; Sun, J.; Huang, Y.; Lan, X.; Lei, C.; Zhou, Y.; et al. Detection of copy number variations and their effects in Chinese bulls. BMC Genom. 2014, 15, 480. [CrossRef]

38. Zhao, C.; Tian, F.; Yu, Y.; Luo, J.; Hu, Q.; Bequette, B.J.; Baldwin, R.L.; Liu, G.; Zan, L.; Updike, M.S.; et al. Muscle transcriptomic analyses in Angus cattle with divergent tenderness. Mol. Biol. Rep. 2011, 39, 4185-4193. [CrossRef]

39. Gilbert, R.P.; Bailey, D.R.; Shannon, N.H. Linear body measurements of cattle before and after 20 years of selection for postweaning gain when fed two different diets2. J. Anim. Sci. 1993, 71, 1712-1720. [CrossRef]

40. Rio, D.C.; Ares, M.; Hannon, G.J.; Nilsen, T.W. Purification of RNA Using TRIzol (TRI Reagent); Cold Spring Harbor Laboratory Press: Cold Spring Harbor, NY, USA, 2010.

41. Hou, Y.; Liu, G.E.; Bickhart, D.M.; Cardone, M.F.; Wang, K.; Kim, E.S.; Matukumalli, L.K.; Ventura, M.; Song, J.; VanRaden, P.M.; et al. Genomic characteristics of cattle copy number variations. Genom. 2011, 12, 127. [CrossRef]

42. Hou, Y.; Bickhart, D.M.; Hvinden, M.L.; Li, C.; Song, J.; Boichard, D.A.; Fritz, S.; Eggen, A.; DeNise, S.; Wiggans, G.R.; et al. Fine mapping of copy number variations on two cattle genome assemblies using high density SNP array. BMC Genom. 2012, 13, 376. [CrossRef] [PubMed]

43. Bickhart, D.M.; Hou, Y.; Schroeder, S.G.; Alkan, C.; Cardone, M.F.; Matukumalli, L.K.; Song, J.; Schnabel, R.D.; Ventura, M.; Taylor, J.F.; et al. Copy number variation of individual cattle genomes using next-generation sequencing. Genome Res. 2012, 22, 778-790. [CrossRef] [PubMed]

44. Bae, J.S.; Cheong, H.S.; Kim, L.H.; NamGung, S.; Park, T.J.; Chun, J.Y.; Kim, J.Y.; Pasaje, C.F.A.; Lee, J.S.; Shin, H.D. Identification of copy number variations and common deletion polymorphisms in cattle. BMC Genom. 2010, 11, 232. [CrossRef] [PubMed]

45. Goshu, H.A.; Chu, M.; Xiaoyun, W.; Pengjia, B.; Zhi, D.X.; Yan, P. Genomic copy number variation of the $\mathrm{CHKB}$ gene alters gene expression and affects growth traits of Chinese domestic yak (Bos grunniens) breeds. Mol. Genet. Genom. 2019, 294, 549-561. [CrossRef] [PubMed]

46. Liu, G.E.; Hou, Y.; Zhu, B.; Cardone, M.F.; Jiang, L.; Cellamare, A.; Mitra, A.; Alexander, L.J.; Coutinho, L.L.; Dell'Aquila, M.E.; et al. Analysis of copy number variations among diverse cattle breeds. Genome Res. 2010, 20, 693-703. [CrossRef]

47. Liu, M.; Liu, M.; Li, B.; Zhou, Y.; Huang, Y.; Lan, X.; Qu, W.; Qi, X.; Bai, Y.; Chen, H. Polymorphisms of FLII implicate gene expressions and growth traits in Chinese cattle. Mol. Cell. Probes 2016, 30, 266-272. [CrossRef]

48. Saremi, B.; Sauerwein, H.; Dänicke, S.; Mielenz, M. Technical note: Identification of reference genes for gene expression studies in different bovine tissues focusing on different fat depots. J. Dairy Sci. 2012, 95, 3131-3138. [CrossRef]

49. Tukey, J.W. Comparing Individual Means in the Analysis of Variance. Biometrics 1949, 5, 99. [CrossRef]

50. Zhang, H.; Meltzer, P.; Davis, S. RCircos: An R package for Circos 2D track plots. BMC Bioinform. 2013, 14, 244. [CrossRef]

51. Hao, D.; Thomsen, B.; Bai, J.; Peng, S.; Lan, X.; Huang, Y.; Wang, X.; Chen, H. Expression Profiles of the MXD3 Gene and Association of Sequence Variants with Growth Traits in Xianan and Qinchuan Cattle. Vet. Med. Sci. 2020, 10, 1002. [CrossRef]

52. Fouilloux, M.N.; Renand, G.; Gaillard, J.; Ménissier, F. Genetic parameters of beef traits of Limousin and Charolais progeny-ested AI sires. Genet. Sel. Evol. 1999, 31, 465. [CrossRef]

53. Ott, J.; Kamatani, Y.; Lathrop, M. Family-based designs for genome-wide association studies. Nat. Rev. Genet. 2011, 12, 465-474. [CrossRef] [PubMed]

54. Wang, X.; Ma, P.; Liu, J.; Zhang, Q.; Zhang, Y.; Ding, X.; Jiang, L.; Wang, Y.; Zhang, Y.; Sun, D.; et al. Genome-wide association study in Chinese Holstein cows reveal two candidate genes for somatic cell score as an indicator for mastitis susceptibility. BMC Genet. 2015, 16, 111. [CrossRef] [PubMed]

55. Yu, J.; Pressoir, G.; Briggs, W.H.; Bi, I.V.; Yamasaki, M.; Doebley, J.F.; McMullen, M.D.; Gaut, B.S.; Nielsen, D.M.; Holland, J.B.; et al. A unified mixed-model method for association mapping that accounts for multiple levels of relatedness. Nat. Genet. 2005, 38, 203-208. [CrossRef]

56. Goddard, M.E.; Hayes, B.J. Mapping genes for complex traits in domestic animals and their use in breeding programmes. Nat. Rev. Genet. 2009, 10, 381-391. [CrossRef] 
57. Mills, R.E.; Walter, K.; Stewart, C.; Handsaker, R.E.; Chen, K.; Alkan, C.; Abyzov, A.; Yoon, S.C.; Ye, K.; Cheetham, R.K.; et al. Mapping copy number variation by population-scale genome sequencing. Nature 2011, 470, 59-65. [CrossRef]

58. Haraksingh, R.R.; Snyder, M.P. Impacts of variation in the human genome on gene regulation. J. Mol. Biol. 2013, 425, 3970-3977. [CrossRef]

59. Stranger, B.E.; Forrest, M.S.; Dunning, M.; Ingle, C.E.; Beazlsy, C.; Thorne, N.; Redon, R.; Bird, C.P.; De Grassi, A.; Lee, C.; et al. Relative impact of nucleotide and copy number variation on gene phenotypes. Science 2007, 315, 848-853. [CrossRef]

60. Luo, R.; Sanders, S.J.; Tian, Y.; Voineagu, I.; Huang, N.; Chu, S.H.; Klei, L.; Cai, C.; Ou, J.; Lowe, J.K.; et al. Genome-wide transcriptome profiling reveals the functional impact of rare de novo and recurrent CNVs in autism spectrum disorders. Am. J. Hum. Genet. 2012, 91, 38-55. [CrossRef]

61. Rockman, M.V.; Kruglyak, L. Genetics of global gene expression. Nat. Rev. Genet. 2006, 7, 862-872. [CrossRef]

62. Gamazon, E.R.; Stranger, B.E. The impact of human copy number variation on gene expression. Briefings Funct. Genom. 2015, 14, 352-357. [CrossRef] [PubMed]

(C) 2020 by the authors. Licensee MDPI, Basel, Switzerland. This article is an open access article distributed under the terms and conditions of the Creative Commons Attribution (CC BY) license (http://creativecommons.org/licenses/by/4.0/). 